\title{
Effectiveness of Critical Thinking about Radicalism Issue (CTRI) on Critical Reading Activities: A Quasi Experimental Study
}

\author{
Nuria Reny Hariyati; Hespi Septiana \\ Akademi Farmasi Surabaya, Indonesia
}

http://dx.doi.org/10.18415/ijmmu.v6i3.1019

\begin{abstract}
This research explains about increasing the ability to think critically to ward off radical issues in critical reading activities in college. This research approach uses a quasi-Times Design Series with Control Group experiment that uses two classes of the same level. The analysis of this study used One Way Anova with a significance level of 0.05 . The results and discussion of this study indicate there is significance, namely 0.049 in the final test of the two groups, which means that there are significant differences in CTRI (Critical Thingking about Radicalism Issue) on critical reading learning. Thus, CTRI (Critical Thingking about Radicalism Issue) has a significant effect on critical reading learning.
\end{abstract}

Keywords: Critical Thinking; Radical Issues; Critical Reading

\section{Introduction}

Critical thinking is now an important demand in college. This ability is very important possessed by students, especially facing the study of radical issues that are hotly debated and debated by academics and non-academics. Critical thinking itself according to Paul, R., \& Elder (2012), Ferguson \& Lavalette (2013), Holm (2018) is the ability to think using the decision making process are strategic planning, scientific process, and problem solving. This article is a study of the concepts of critical reading and critical thinking. Critical reading according to Ferguson \& Lavalette (2013), Baek Jiyeon \& Choi Jin Oh. (2012) in terms of various definitions which include skills involving various types and levels of cognitive domains.

It also discussed what could influence the type of reading needed, namely the radical issue. To read critically, it is necessary to look closely at the concept of radical issues themselves. Woodward (2013) said radical issues as a mental process, radical issues are one of the important topics to be presented. Therefore, understanding the thinking elements of radical religious, social and cultural issues can be used further to analyze the process of critical thinking. Regarding the need to implement a process that is more easily identified, a study that combines critical thinking in reading learning with the current radical issue of religion in Indonesia to see the effectiveness of critical thinking. Because this study is intended to place critical thinking on radical issues in order to synergize with critical reading, it is important to build a deeper understanding of the quality of what a critical reader must have. 
Research on critical reading in the last five years about critical reading has been done Hariyati, (2016) researching on the Implementation of the 3P Reading Strategy (Perluas Jangkauan Mata, Percepat Gerak Mata, Dan Perkecil Regresi) in State High School; Hariyati and Syakur (2018) examined the Implementation of Critical Reading Strategies at Akademi Farmasi Surabaya to Support Literacy Skills Toward the Industrial Revolution Era 4.0; Öz and Eder (2018) who examine radical social issues; DeszczTryhubczak (2018) who examines reading of fiction based on radical issues. Hariyati \& Ahmadi (2019) researching about Susiso's critical reading perspective. Thus research on the influence of CTRI (Critical Thingking about Radicalism Issue) on critical reading activities in higher education has never been done.

In connection with the phenomenon of critical reading until now no one has linked critical reading with radicalism. In fact, critical reading and radicalism is one thing that is very urgent. Someone who is less able to read critically will be easily provoked by writing with the theme of radicalism. For this reason, this article raises critical reading in relation to radicalism. In this context, critical reading is one strategy in understanding texts that have an element of radicalism.

\section{Methods}

This research method uses a quasi experimental method. Quasi-experiments according to White \& Sabarwal (2014), Pattison, Gutwill, Auster, and Cannady (2019) are studies that focus on the process of group selection determined by a random process. This study uses a quasi experiment with the TimesSeries Design with Control Group design, which is two groups that have been formed without any reengineering by researchers. Groups are determined based on existing classes. The group is divided into two groups, the experimental group and the control group.

\begin{tabular}{ll}
\hline Group & \multicolumn{1}{c}{ Tretest } \\
\hline Experiment Class & $\begin{array}{l}\text { Learning Critical Reading } \\
\text { with CTRI (Critical Thingking } \\
\text { about Reading Issue) Strategy }\end{array}$ \\
A1-18 &
\end{tabular}

Test1

Test2

Control Class

A4-18

Learning Critical reading

Table 1

The data of this study, namely the test scores of the two groups of Akademi Farmasi Surabaya students in the 2018/2019 school year. The research control group, namely A4-18 class and experimental group, namely class A1-18 with twenty students each. The two groups conducted, (1) the initial test, (2) the implementation of learning by the CTRI method for the experimental class, (3) the final test. The group was analyzed by One Way Anova Marsden \& Torgerson (2012), which is to test the difference in the mean of the two groups and analysis of data variability. This analysis uses SPSS for Windows with a significance level of 0.05 . 


\section{Discussion}

Anova One way test Anova is used to analyze the results of the initial and final tests which are explained as follows.

\section{Pretest Discussion}

The results of the initial test analysis showed that the experimental group and the control group had balanced abilities. The purpose of the statement is the ability of the two groups is almost the same. With these same capabilities, quasi experimental research can be done without engineering. The initial test will take place at the second meeting in the Indonesian language course. The initial test is carried out by the experimental class and the control class without the critical reading learning activities from 8:00 to 09:40. Respondents were given a reading that is closely related to the current radical issues then respondents were asked to answer the questions provided. Anova test results early tests using SPSS for Windows can be known as follows.

\section{Descriptives}

\begin{tabular}{|c|c|c|c|c|c|c|c|c|}
\hline & \multirow[b]{2}{*}{$\mathrm{N}$} & \multirow[b]{2}{*}{ Mean } & \multirow[b]{2}{*}{$\begin{array}{c}\text { Std. } \\
\text { Deviation }\end{array}$} & \multirow[b]{2}{*}{$\begin{array}{l}\text { Std. } \\
\text { Error }\end{array}$} & \multicolumn{2}{|c|}{$\begin{array}{l}95 \% \text { Confidence } \\
\text { Interval for Mean }\end{array}$} & \multirow[b]{2}{*}{$\begin{array}{c}\text { Minim } \\
\text { um } \\
\end{array}$} & \multirow[b]{2}{*}{$\begin{array}{c}\text { Maxim } \\
\text { um }\end{array}$} \\
\hline & & & & & $\begin{array}{l}\text { Lower } \\
\text { Bound }\end{array}$ & $\begin{array}{l}\text { Upper } \\
\text { Bound }\end{array}$ & & \\
\hline kelas kontrol & 20 & 72.60 & 2.280 & .510 & 71.53 & 73.67 & 70 & 78 \\
\hline $\begin{array}{l}\text { kelas } \\
\text { eksperimen }\end{array}$ & 20 & 72.55 & 3.379 & .756 & 70.97 & 74.13 & 67 & 82 \\
\hline Total & 40 & 72.58 & 2.845 & .450 & 71.66 & 73.49 & 67 & 82 \\
\hline
\end{tabular}

Test of Homogeneity of Variances

\begin{tabular}{r|rr|r|r}
$\begin{array}{l}\text { test } \\
\text { Levene Statistic }\end{array}$ & df1 & \multicolumn{2}{c}{ df2 } & Sig. \\
\hline 1.468 & \multicolumn{1}{c}{1} & 38 & .233 \\
\hline \multicolumn{5}{c}{ Table 3 }
\end{tabular}

\section{ANOVA}

\begin{tabular}{lr|r|r|r|r} 
test & \multicolumn{1}{c}{ Sum of Squares } & df & Mean Square & F & \multicolumn{1}{c}{ Sig. } \\
\hline Between Groups & .025 & 1 & .025 & .003 & .957 \\
\hline Within Groups & 315.750 & 38 & 8.309 & & \\
\hline Total & 315.775 & 39 & & & \\
\hline
\end{tabular}

Table 4

The Descriptives table it is known that the control class respondent averaged 72.60 and the experimental class averaged 72.58. From the test table of homogeneity of variances shows that the 
variants of the two groups are the same, namely $(\mathrm{P}$-value $=0.233)$ so that the Anova test can be used to test this relationship. Furthermore, from the ANOVA table obtained a significance level of 0.957 which means> 0.05. Thus it can be said that the initial test results did not show a significant difference in the two classes with respect to critical reading activities.

\section{Posttest Discussion}

The results of the final test analysis showed that the experimental class had increased. Treatments given to the experimental class included four stages, namely (1) Clarity; (2) Accuracy; (3) Precision; (4) Relevance; and (5) Depth. Giving these treatments for one semester (eleven meetings) in the experimental class while the control class gets critical reading material according to $\mathrm{CP}$ ) learning outcomes) without being specific to a particular method. The final test is carried out at the eleventh meeting in the Indonesian language course. The final test is carried out by the experimental class and the control class from 08.00 to 09.40 . Respondents were given a reading that is closely related to the current radical issues then respondents were asked to answer the questions provided. Anova test results using SPSS for Windows can be known as follows.

\section{Descriptives}

\begin{tabular}{|c|c|c|c|c|c|c|c|c|}
\hline & \multirow[b]{2}{*}{$\mathrm{N}$} & \multirow[b]{2}{*}{ Mean } & \multirow[b]{2}{*}{$\begin{array}{c}\text { Std. } \\
\text { Deviation }\end{array}$} & \multirow[b]{2}{*}{$\begin{array}{l}\text { Std. } \\
\text { Error }\end{array}$} & \multicolumn{2}{|c|}{$\begin{array}{l}95 \% \text { Confidence } \\
\text { Interval for Mean }\end{array}$} & \multirow[b]{2}{*}{$\begin{array}{c}\text { Minim } \\
\text { um }\end{array}$} & \multirow[b]{2}{*}{$\begin{array}{c}\text { Maxim } \\
\text { um }\end{array}$} \\
\hline & & & & & $\begin{array}{l}\text { Lower } \\
\text { Bound }\end{array}$ & $\begin{array}{l}\text { Upper } \\
\text { Bound }\end{array}$ & & \\
\hline kelas kontrol & 20 & 72.75 & 1.916 & .428 & 71.85 & 73.65 & 70 & 78 \\
\hline $\begin{array}{l}\text { kelas } \\
\text { eksperimen }\end{array}$ & 20 & 74.20 & 2.546 & .569 & 73.01 & 75.39 & 71 & 82 \\
\hline Total & 40 & 73.48 & 2.342 & .370 & 72.73 & 74.22 & 70 & 82 \\
\hline
\end{tabular}

Table 5

\section{Test of Homogeneity of Variances}

\begin{tabular}{r|c|c|c}
$\begin{array}{l}\text { test } \\
\text { Levene Statistic }\end{array}$ & df1 & df2 & Sig. \\
\hline 1.263 & 1 & 38 & .268 \\
\hline \multicolumn{5}{c}{ Table 6}
\end{tabular}

\section{ANOVA}

\begin{tabular}{lr|r|r|r|r} 
test & \multicolumn{1}{l}{ Sum of Squares } & df & Mean Square & \multicolumn{1}{c}{ F } & \multicolumn{1}{c}{ Sig. } \\
\hline Between Groups & 21.025 & 1 & 21.025 & 4.141 & .049 \\
\hline Within Groups & 192.950 & 38 & 5.078 & & \\
\hline Total & 213.975 & 39 & & \\
\hline
\end{tabular}

Table 7 
The descriptives table it is known that the control class respondent averaged 72.75 and the experimental class averaged 74.20. From the test table of homogeneity of variances shows that the variants of the two groups are the same, namely $(\mathrm{P}$-value $=0.268)$ so that the Anova test can be used to test this relationship. Furthermore, from the ANOVA table obtained significance level of 0.049 which means $<0.05$. Thus it can be said that the final test results show a significant difference between the two groups on critical reading activities. Another meaning of the statement is that there is a significant effect of the CTRI method on critical reading activities in the experimental group.

The final test results of the experimental class and the control class show that the experimental class experienced the highest score increase of 82 compared to the control class which experienced an increase in the highest score of 78 which can be seen in the following diagram.

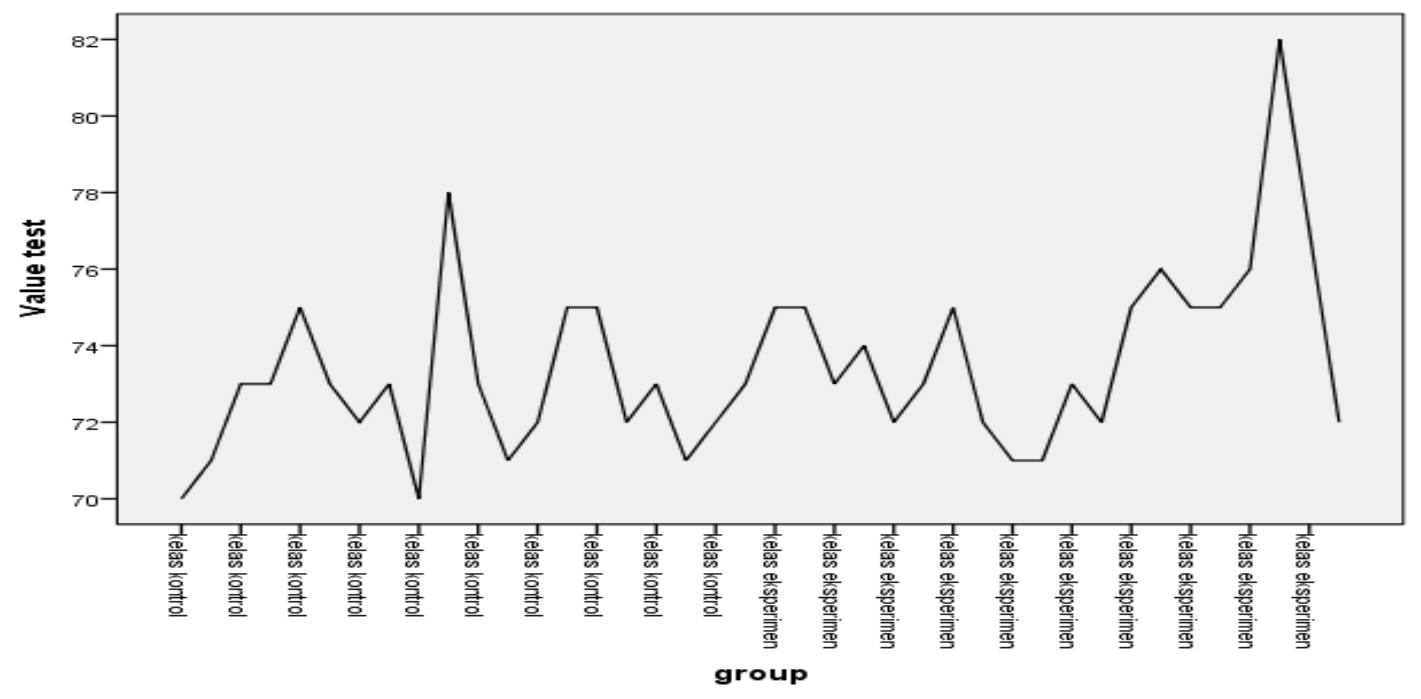

Diagram 1

\section{Acknowledgements}

This article have funded by Direktorat Riset dan Pengabdian Masyarakat, Direktorat Jenderal Penguatan Riset dan Pengembangan Kementerian Riset, Teknologi, dan Pendidikan Tinggi Republik Indonesia as Penelitian Dosen Pemula output in 2019.

\section{Reference}

Baek Jiyeon \& Choi Jin Oh. (2012). The Effects of a Reading Comprehension Monitoring Strategy on Critical Reading, Reading Efficacy, and Reading Attitudes. Journal Of Research In Curriculum Instruction, 16(2), 421-439. doi: 10.24231/rici.2012.16.2.421

Deszcz-Tryhubczak, J. (2018). Reading About Solidarity and Collective Action: Social Minds in Radical Fantasy Fiction. Children's Literature in Education. 
Ferguson, I., \& Lavalette, M. (2013). Critical and radical social work: an introduction. Critical And Radical Social Work, 1(1), 3-14. doi: 10.1332/204986013×665938

Hariyati, N. R. (2016).Implementasi Strategi Membaca 3 P (Perluas Jangkauan Mata, Percepat Gerak Mata, Dan Perkecil Regresi) Di Sma Negeri 1 Ngoro-Jombang. Inovasi 10 (4), 325-338.

Hariyati, N. R. \& Syakur, A. (2018). Penerapan Strategi Membaca Kritis Di Akademi Farmasi Surabaya Untuk Menunjang Kecakapan Literasi Menuju Era Revolusi Industri 4.0. Prosiding Seminar Nasional \& Internasional 1 (1).

Hariyati, N. R. \& Ahmadi, A. (2018). Effectiveness Learning of Critical Reading Using Susiso Model. 2nd Workshop on Language, Literature and Society for Education. Proceeding international conference.

Holm, N. (2018). Critical capital: cultural studies, the critical disposition and critical reading as elite practice. Cultural Studies, 1-24. doi: 10.1080/09502386.2018.1549265

Marsden, E., \& Torgerson, C.J. (2012). Single group, pre- and post-test research designs: Some methodological concerns. Oxford Review of Education, 38, 583-616.

Öz, Ö. and Eder, M. (2018), 'Problem Spaces' and Struggles Over the Right to the City: Challenges of Living Differentially in a Gentrifying Istanbul Neighborhood. Int. J. Urban Reg. Res., 42: 10301047. doi: $\underline{10.1111 / 1468-2427.12656}$

Pattison, S., Gutwill, J., Auster, R. and Cannady, M. (2019). Experimental and Quasi-Experimental Designs in Visitor Studies: A Critical Reflection on Three Projects. Visitor Studies, 22(1), pp.4366.

Paul, R. \& Elder, L. (2012). The International Critical Thinking Reading and Writing Test. USA: Tomales.

White, H., \& S. Sabarwal (2014). Quasi-experimental Design and Methods, Methodological Briefs: Impact Evaluation 8, UNICEF Office of Research, Florence.

Woodward, R. (2013). Some reflections on critical and radical social work literature. Critical And Radical Social Work, 1(1), 135-140. doi: 10.1332/204986013x666045.

\section{Copyrights}

Copyright for this article is retained by the author(s), with first publication rights granted to the journal. This is an open-access article distributed under the terms and conditions of the Creative Commons Attribution license (http://creativecommons.org/licenses/by/4.0/). 